\title{
Occurrence of Fasciola bepatica (Linnaeus, 1758) infection in Brazilian cattle of Minas Gerais, Brazil
}

\author{
Ocorrência de Fasciola hepatica Linnaeus, 1758 em rebanhos bovinos do estado de Minas Gerais, Brasil \\ Walter dos Santos Lima ${ }^{1 *}$; Lanuze Rose Mozzer Soares ${ }^{1}$; Thales Augusto Barçante²; \\ Marcos Pezzi Guimaraes ${ }^{1}$; Joziana Muniz de Paiva Barçante ${ }^{1}$
}

${ }^{1}$ Departamento de Parasitologia, Instituto de Ciências Biológicas, Universidade Federal de Minas Gerais - UFMG

${ }^{2}$ Curso de Medicina Veterinária, Pontifícia Universidade Católica de Minas Gerais - UFMG, Campus Poços de Caldas

Received May 31, 2008

Accepted February 27, 2009

\begin{abstract}
Fasciolosis is a parasitic disease which is caused by digenetic trematodes, such as Fasciola hepatica, and which occurs worldwide. The disease causes significant economic losses in cattle because of the reduction in milk and meat production and because the parasitized livers have no economic value. Also, abortion and mortality rates increase. To determine the occurrence and dispersal of $F$. hepatica in the state of Minas Gerais, fecal samples were collected from bovines aged 12 months and older between April 2005 and April 2006. The bovines came from 1,251 rural farms of 120 municipalities/cities in Minas Gerais. Water was collected to ascertain the presence of the intermediate host in the properties where infected bovines were found. A total of 16 municipalities had infected bovines and 13 had the presence of Lymnaea columella. We detected infected bovines in $70 \%$ of the rural farms visited in the municipality of Itajubá. Itajubá was also found to have infected snails with the larval stage of $F$. hepatica. The results revealed that infection by $F$. hepatica in bovines of Minas Gerais was associated with the presence of the intermediate host and favorable epidemiological factors, drawing attention to the necessity of adopting proper control measures in the area.
\end{abstract}

Keywords: Fasciola hepatica, Lymnaea columella, Bovine fasciolosis.

\section{Resumo}

A fasciolose é uma doença parasitária que ocorre em todo o mundo e é causada por um trematódeo digenético conhecido como Fasciola hepatica. A doença é responsável por causar perdas econômicas significativas em bovinos, devido à diminuição na produção de carne e leite, condenação de fígados parasitados e aumento na mortalidade. Para determinar a ocorrência e a dispersão da $F$. hepatica no estado de Minas Gerais, amostras de fezes de bovinos com idade superior a 12 meses foram coletadas, no período de Abril de 2005 a Abril de 2006. Foram examinados bovinos provenientes de 1.251 propriedades rurais de 120 municípios do estado de Minas Gerais. Coleçóes hídricas também foram examinadas, a fim de verificar a presença de hospedeiros intermediários nas propriedades onde foram encontrados bovinos parasitados. Para um total de 16 municípios foi relatada a presença de bovinos infectados por $F$. hepatica e destes, 13 apresentaram também o molusco Lymnaea columella. Foi possível diagnosticar bovinos infectados em $70 \%$ das propriedades visitadas no município de Itajubá. Além disso, no município de Itajubá foi possível detectar a presença de moluscos naturalmente infectados com diferentes estádios larvais de $F$. hepatica. Os resultados evidenciam a necessidade de medidas de controle para esta parasitose na área estudada, uma vez que foi possível verificar a presença de bovinos e moluscos infectados por $F$. hepatica, associada a fatores epidemiológicos favoráveis a dispersão do parasito.

Palavras-chave: Fasciola hepatica, Lymnaea columella, Fasciolose bovina.

\section{Introduction}

Fascioliasis is a parasitic disease caused by the flukes Fasciola hepatica and Fasciola gigantica, which are the two most economically important helminthic parasites of animals (YOKANANTH et al.,

*Corresponding author: Walter dos Santos Lima

Departamento de Parasitologia, Instituto de Ciências Biológicas,

Universidade Federal de Minas Gerais - UFMG, Av. Presidente Antônio

Carlos, 6627, CP 486, Campus Pampulha, CEP 31270-910,

Belo Horizonte - MG, Brasil, e-mail: wlima@icb.ufmg.br

Supported by: FAPEMIG and CNPq.
2005). Disease causes large economic losses in cattle due the reduction in milk and meat production, and because the parasitized livers have no economic value. Also abortions, increased mortality, and the expense of control measures (FARIA et al., 2005). The worldwide losses in animal productivity because of fascioliasis have been estimated at over USD $\$ 3.2$ billion per annum (SPITHILL et al., 1997). By contrast, demand for animal-derived food in developing countries is expected to increase by $2.8 \%$ per annum 
from 1993 to 2020 (YOKANANTH et al., 2005). It is believed that the control of fascioliasis could contribute significantly to improve animal production.

The largest enzootic area of Brazil is located in the Southern part of the country, with smaller foci in the Southeastern and Midwestern regions. The growing animal trade among cattle owners from various regions of Brazil has contributed to an increase in the profile of $F$. hepatica distribution in recent years. In Minas Gerais, for example, an important meat and dairy-producing area situated in the Southeastern region of Brazil, the climatic factors associated with management practices can affect helminthic infection in cattle, including $F$. hepatica infection. The State of Minas Gerais belongs to an enzootic area of fascioliasis. Sporadic reports of the disease have been made in some parts of the state, especially in the city of Itajubá (SERRA-FREIRE et al., 1995; FARIA et al., 2005); however, there are few studies (COELHO et al., 2003; FARIA et al., 2005) that account for a prevalence of $F$. hepatica infection, its epidemiology, and the control done in this area.

In this study we aimed to determine the occurrence and dispersion of $F$. hepatica in eight regions of the state of Minas Gerais, which is considered an important meat and dairy-producing state in Brazil.

\section{Material and Methods}

The present study was done between April 2005 and April 2006 in 1,251 rural farms in 120 municipalities/cities distributed in eight regions of Minas Gerais (Triangulo/Alto do Parnaíba; Central Mineira; Vale do Rio Doce; Metalurgica; Oeste de Minas; Campo das Vertentes; Zona da Mata; and Sul/Sudoeste de Minas). These regions hold almost 14 million bovine animals, which correspond to $70 \%$ of the cattle in Minas Gerais.

The number of properties to be included in the present study was defined by Instituto Mineiro de Agropecuária (IMA) using the WinEpiscope ${ }^{\oplus}$ program, and ranged from nine to 11 farms located in different places in each city. From each farm, nine animals at least 12 months old were chosen randomly for the study. Fecal samples of about $40 \mathrm{~g}$ were collected individually from the rectum of each animal. Feces were kept in refrigerated boxes until sent to the laboratory. A total of 6,255 fecal samples were analyzed using the Girão and Ueno techniques (GIRÃO; UENO, 1985) for the presence of Fasciola hepatica eggs. The fecal debris was stained with a few drops of $1 \%$ methylene blue to differentiate plant matter (blue) from eggs of $F$. hepatica (yellow). The search for eggs was performed under stereomicroscope at a magnification of 40 times.

In the period from May 2005 to April 2006, water was collected to be examined for the presence of the intermediate host on the farms where there were infected bovines. Every possible form of water source was examined: waterhole, tap water, waterfall, puddles, swamps, and creeks.

Sampling was performed by using the quadrant method (AMATO et al., 1986) in which a $1 \mathrm{~m}^{2}$ area was randomly selected for each plot, and snails were collected from the water with a steel sieve (1 mm mesh) or from aquatic plants, during a period of 20-30 minutes of investigation. The collected snails were then placed in wet gauze strips and transported to the laboratory. Snail identification was processed according to Paraense $(1983,1986)$ and Lymnaea snails were dissected under a stereomicroscope at a magnification of 40 times to look for larval stages of $F$. hepatica.

\section{Results}

Occurrence of infected animals was determined by the presence of Fasciola hepatica eggs in the feces exam. From the eight regions of the State of Minas Gerais included in this study, four were positive for $F$. hepatica eggs in the feces of bovines (Figure 1). A total of 16 municipalities had infected bovines (Table 1). Some properties, such as those in the municipalities of Uberlândia, Bicas, Divinópolis, Betim, Itabira, and Igarapé, were commercial farms with a high rate of animals interchange among bovine raisers. For this reason, it was not possible to establish the origin of the animals from those farms that tested positive. On the other hand, it was possible to find the intermediate host of $F$. hepatica in almost every farm in those municipalities.

The collected intermediate host of $F$. hepatica was identified as L. columella. It was found in 13 municipalities where $F$. hepatica eggs were detected in the bovine feces (Table 1). Some of the snails were found in water tanks, but the majority were in drainage ditches and were associated with aquatic plants such as Eichornia azurea and Heteranthera reniformis. Lymnaea columella eggs were found on low leaves of these plants as well as on Brachiaria decumbens leaves. The total number of collected snails ranged from 0 to 135 . The greatest number of snails was collected in drainage pipes and ditches in meadows in the city of Itajubá, where 135 species of L. columella were collected on seven farms with positive animals. The municipality of Itajubá was the only location in which was detected the presence of natural infected snails with the larval stage of $F$. hepatica. The snails were found in two farms situated in meadows near Sapucaí River.

A total of 492 snails of $L$. columella were collected and examined for intramolluskan stages of $F$. hepatica (Table 1). The municipality of Itajubá was the only one where natural infected snails with larval

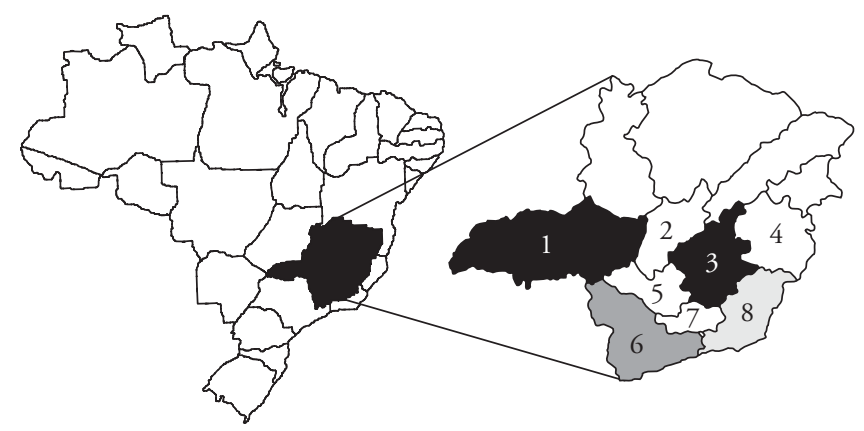

Figure 1. Location of the eight studied regions in Minas Gerais State in Southeastern Brazil (1 - Triângulo Mineiro/Alto Parnaíba; 2 - Central Mineira; 3 - Metalurgica; 4 - Vale do Rio Doce; 5 - Sul/Sudoeste de Minas; 6 - Oeste de Minas; 7 - Campo das Vertentes; 8 - Zona da Mata). The colored regions (Regions 1, 3, 6 and 8) represent the locations where Fasciola hepatica parasitized bovines were found. 
Table 1. Geographical location of municipalities related to the presence of Fasciola hepatica naturally infected bovines and Lymnaea columella in Minas Gerais State.

\begin{tabular}{|c|c|c|c|c|c|}
\hline \multirow{2}{*}{ Municipalities } & \multicolumn{2}{|c|}{ Number of farms } & \multicolumn{2}{|c|}{ Number of Lymnaea } & \multirow{2}{*}{ Geographical location } \\
\hline & Sampled & Positive (\%) & Sampled & Positive (\%) & \\
\hline Uberlândia & 11 & $1(9.1)$ & 0 & $0(0.0)$ & $18^{\circ} 55^{\prime} 07^{\prime \prime} \mathrm{S}$ and $48^{\circ} 16^{\prime} 38^{\prime \prime} \mathrm{W}$ \\
\hline Juiz de Fora & 10 & $1(10.0)$ & 33 & $0(0.0)$ & $21^{\circ} 45^{\prime} 51^{\prime \prime} \mathrm{S}$ and $43^{\circ} 21^{\prime} 01^{\prime \prime} \mathrm{W}$ \\
\hline Bicas & 9 & $1(11.1)$ & 28 & $0(0.0)$ & $21^{\circ} 43^{\prime} 31^{\prime \prime} \mathrm{S}$ and $43^{\circ} 03^{\prime} 34^{\prime \prime} \mathrm{W}$ \\
\hline São Gonçalo do Sapucaí & 10 & $2(20.0)$ & 8 & $0(0.0)$ & $21^{\circ} 53^{\prime} 32^{\prime \prime} \mathrm{S}$ and $45^{\circ} 35^{\prime} 43^{\prime \prime} \mathrm{W}$ \\
\hline Piranguinho & 10 & $4(40.0)$ & 46 & $0(0.0)$ & $21^{\circ} 53^{\prime} 32^{\prime \prime} \mathrm{S}$ and $45^{\circ} 35^{\prime} 43^{\prime \prime} \mathrm{W}$ \\
\hline Itajubá & 10 & $7(70.0)$ & 135 & $4(2.96)$ & $22^{\circ} 25^{\prime} 32^{\prime \prime} \mathrm{S}$ and $45^{\circ} 27^{\prime} 10^{\prime \prime} \mathrm{W}$ \\
\hline Varginha & 10 & $1(10.0)$ & 9 & $0(0.0)$ & $21^{\circ} 33^{\prime} 05^{\prime \prime} \mathrm{S}$ and $42^{\circ} 25^{\prime} 49^{\prime \prime} \mathrm{W}$ \\
\hline Cachoeira de Minas & 10 & $4(40.0)$ & 39 & $0(0.0)$ & $22^{\circ} 21^{\prime} 18^{\prime \prime} \mathrm{S}$ and $45^{\circ} 45^{\prime} 44^{\prime \prime} \mathrm{W}$ \\
\hline Divinópolis & 10 & $1(10.0)$ & 0 & $0(0.0)$ & $20^{\circ} 08^{\prime} 20^{\prime \prime} \mathrm{S}$ and $44^{\circ} 53^{\prime} 02^{\prime \prime} \mathrm{W}$ \\
\hline Careaçu & 10 & $3(30.0)$ & 32 & $0(0.0)$ & $22^{\circ} 02^{\prime} 35^{\prime \prime} \mathrm{S}$ and $45^{\circ} 41^{\prime} 57^{\prime \prime} \mathrm{W}$ \\
\hline Brasópolis & 10 & $3(30.0)$ & 55 & $0(0.0)$ & $22^{\circ} 02^{\prime} 35^{\prime \prime} \mathrm{S}$ and $45^{\circ} 41^{\prime} 57^{\prime \prime} \mathrm{W}$ \\
\hline Santa Rita do Sapucaí & 10 & $2(20.0)$ & 66 & $0(0.0)$ & $22^{\circ} 15^{\prime} 08^{\prime \prime} \mathrm{S}$ and $45^{\circ} 42^{\prime} 12^{\prime \prime} \mathrm{W}$ \\
\hline Betim & 10 & $1(10.0)$ & 6 & $0(0.0)$ & $19^{\circ} 58^{\prime} 04^{\prime \prime} \mathrm{S}$ and $44^{\circ} 11^{\prime} 54^{\prime \prime} \mathrm{W}$ \\
\hline Itabira & 10 & $1(10.0)$ & 0 & $0(0.0)$ & $19^{\circ} 37^{\prime} 09^{\prime \prime} \mathrm{S}$ and $43^{\circ} 13^{\prime} 37^{\prime \prime} \mathrm{W}$ \\
\hline Itabirito & 10 & $1(10.0)$ & 18 & $0(0.0)$ & $20^{\circ} 15^{\prime} 12^{\prime \prime} \mathrm{S}$ and $43^{\circ} 48^{\prime} 05^{\prime \prime} \mathrm{W}$ \\
\hline Igarapé & 10 & $1(10.0)$ & 17 & $0(0.0)$ & $20^{\circ} 04^{\prime} 13^{\prime \prime} \mathrm{S}$ and $40^{\circ} 18^{\prime} 06^{\prime \prime} \mathrm{W}$ \\
\hline Total & 160 & 34 & 492 & 4 & - \\
\hline
\end{tabular}

stage of $F$. hepatica was found. Infection rate of $L$. columella with F. hepatica in Itajubá was $2.96 \%$ (four infected snails).

Other snails, such as Physa marmorata, Biomphalaria sp., Drepanotrema sp., and Pomaceae sp., were observed in the same habitat as the intermediate hosts.

\section{Discussion}

Ruminant fascioliasis is a serious problem that causes economic losses in several countries (COELHO, 2003; LIMA, 2003; YOKANANTH et al., 2005). The epidemiology of fascioliasis is related to the ecology of the intermediate host, the habitat where it lives, the presence of water, and climatic conditions (MATTOS et al., 1997). In the present studied area, L. columella was found in the majority $(13 / 16)$ of the places where parasitized bovines were also found.

Natural infection rates of $L$. columella with $F$. hepatica corresponded to $2.96 \%$. These rates are lower than those found in Paraíba Valley (AMATO et al., 1986), which reached 13.9\% in the months of the highest prevalence. The low presence of infected snails was probably because of the collection place and because only one collection was done without considering the seasonality of the population of snails as it is seen in most works on the subject. The importance of seasonality in infection rates of Lymnaea sp. was observed in the Netherlands (GAASENBECK et al., 1992), where infected snails are able to hibernate. Thus, climate may influence infection dynamics of $L$. columella by $F$. hepatica.

Although there are some records of F. hepatica in Minas Gerais, the state is not considered to be within an enzootic area. Nevertheless, the Southern/Southwestern region of Minas Gerais, which includes the municipalities of Itajubá, Cachoeira de Minas, and São Gonçalo do Sapucaí, has several eco-epidemiological conditions that allow the occurrence of $F$. hepatica. Therefore, it is clear that those regions of Minas Gerais can be considered as a focus of hepatic fascioliasis. There are approximately 21 million cattle distributed over $586,000 \mathrm{~km}^{2}$, which is divided into 12 regions based on diversities of physiographic and climatic conditions. Climatic factors associated with management practices can influence helminthic infection in cattle, including $F$. hepatica infection. Furthermore, the presence of $L$. columella snails, associated with the presence of large hydrological sources, such as the Sapuca River that irrigates the region, seems to be an important factor in the dispersion of the parasite to other regions and, subsequently, to a great number of infected bovines.

It was possible to detect infected bovines in $70 \%$ of the rural farms visited in the municipalities of Itajubá. Moreover, Itajubá was related to the presence of snails infected with the larval stage of $F$. hepatica. The intensive animal trade in several areas of the state, in conjunction with the presence of the intermediate host and the unfamiliarity of the farmers regarding the epidemiological factors related to fascioliasis and its transmission, are indicators that the authorities of the Official Animal Health Defense Service must adopt proper control measures in the area.

\section{Acknowledgements}

The authors also thanks Edna Maia for support assistance.

\section{References}

AMATO, S. B. et al. Epidemiology of Fasciola hepática infection in the Paraíba River Valley. Veterinary Parasitology, v. 22, n. 3-4, p. 275-284, 1986. 
COELHO, L. H. L.; LIMA, W. S. Population dynamics of Lymnaea columella and its natural infection by Fasciola hepatica in the State of Minas Gerais, Brazil. Journal of Helminthology, v. 77, n. 1, p. 7-10, 2003.

FARIA, R. N.; CURY, M. C.; LIMA, W. S. Prevalence and dynamics of natural infection with Fasciola hepatica (Linnaeus, 1758) in brazilian cattle. Revue Médicine Véterinaire, v. 156, n. 2, p. 86, 2005.

GAASENBÉCK, C. P. H. et al. An epidemiological study of Fasciola hepatica in the Netherlands. Veterinary Quarterly, v. 14, n. 4, p. 140-144, 1992.

GIRÃO, E. S.; UENO, H. Técnica de Quatro tamises para o diagnóstico coprológico quantitativo da fasciolose dos ruminantes. Pesquisa Agropecuária Brasileira, v. 20, n. 8, p. 905-912, 1985.

MATTOS, M. J. T.; UENO, H.; GONÇALVES, P. C. Ocorrência estacional e bioecologia de Lymnaea columella Say, 1817 (Mollusca,
Lymnaeidae) em habitat natural no Rio Grande do Sul. Revista Brasileira de Medicina Veterinária, v. 19, n. 6, p. 248-251, 1997.

PARAENSE, W. L. Lymnaea columella in Northern Brazil. Memórias do Instituto Oswaldo Cruz, v. 78, n. 4, p. 477-482, 1983.

PARAENSE, W. L. Physa marmorata Guilding, 1828 (Pulmonata: Physidae). Memórias do Instituto Oswaldo Cruz, v. 91, n. 4, p. 459-469, 1986.

SERRA-FREIRE, N. M. et al. Reinvestigação sobre a distribuição da Fasciola hepatica no Brasil. Hora Veterinária, n. 1, p. 19-21, 1995.

SPITHILL, T. W.; PIEDRAFITA, D.; SMOOKER, P. M. Immunological approaches for the control of fasciolosis. International Journal for Parasitology, v. 27, n. 10, p. 1221-1235, 1997.

YOKANANTH, S. et al. Characterization of specific and cross-reacting antigens of Fasciola gigantica by immunoblotting. Parasitology Research, v. 97, n. 1, p. 41-48, 2005. 